\title{
ULTRASTRUCTURAL STUDIES OF SEMEN ABNORMALITIES AND HERPESVIRUS ASSOCIATED WITH CULTURED TESTICULAR CELLS FROM DOMESTIC TURKEYS
}

\author{
R. J. THURSTON, R. A. HESS, H. V. BIELLIER, \\ H. K. ADLDINGER* AND R. F. SOLORZANO* \\ Department of Poultry Husbandry, College of Agriculture, and \\ * Department of Veterinary Microbiology, College of Veterinary Medicine, \\ University of Missouri-Columbia, Columbia, Missouri 65201, U.S.A.
}

\section{(Received 30th December 1974)}

\begin{abstract}
Summary. Abnormal cells and macrophages found in white and yellow turkey semen were studied by electron microscopy. Yellow semen contained many abnormal cells, most of which were large and round or smaller and ellipsoidal. It was concluded that they were aberrant spermatids, with differentiation being more complete in the smaller cells. Only a few cells of the smaller type were detected in normal white semen. Macrophages were occasionally seen in white semen but were numerous in yellow semen. Phagocytic vacuoles of these cells contained structural elements of spermatozoa and abnormal spermatids. Virus particles were not detected in any of the seminal cells observed.

Ultrastructure studies of cultured testicular cells obtained from several of the turkeys examined showed the presence of intranuclear Herpesvirus particles in germinal cells. Macrophages from the testicular cultures seldom were seen with intranuclear Herpesvirus, although these cells commonly were found with Herpesvirus particles and cellular debris contained within phagocytic vacuoles.
\end{abstract}

\section{INTRODUGTION}

Poor fertility of unknown aetiology is often encountered by commercial turkey breeders (Lorenz, 1970). The problem is exacerbated by a lack of warning, since afflicted birds show few if any symptoms. Fertility in turkeys is significantly influenced by the performance of individual males (Kammerer et al., 1972), and it has been suggested that deterioration in semen quality may sometimes account for reduced reproductive performance (McCartney, 1956).

Saeki (1960) showed that low fertility was a problem in cockerels whose semen contained high numbers of crooked-necked spermatozoa. Saeki \& Brown (1962) also found that turkey toms which produced discoloured yellow 
semen did not reproduce as efficiently as males yielding white semen due to the presence of many crooked-necked spermatozoa in the yellow semen. Cherms (1968) provided further evidence that turkey males with yellow semen were less fertile than those producing normal white semen.

Despite the above findings, detailed reports on yellow semen production and its association with low fertility are absent from the literature. In many instances we have found that low fertility in turkey breeders was associated with hens bred to males producing yellow semen. This communication describes the ultrastructure of abnormal cells which were observed in selected yellow and white semen samples from turkeys and confirms that Herpesvirus particles are present within cultured testicular cells, particularly those from males which had produced yellow semen. The data support the work of Adldinger et al. (1974) which indicates that herpesviruses may have a role in abnormal spermatogenesis with concomitant low fertility in the male turkey.

\section{MATERIALS AND METHODS}

\section{Selection of males}

Birds used in this study were yearling bronze or white breeder males maintained by the Poultry Husbandry Department of the University of MissouriColumbia. The semen quality of 210 toms was scored to determine the incidence of yellow semen production and to select males for further electron microscope studies. The flock was sampled in the 4th month of a 6 -month breeding season, at which time the birds were maintained on a $14 \mathrm{hr}$ light $/ 10 \mathrm{hr}$ dark diurnal cycle. Semen was collected by a massage technique (Burrows \& Quinn, 1937) and scored using plasma colour and numbers of abnormal cells as evaluation criteria. For light microscopic examinations, a drop of fresh semen was placed on a slide and mixed approximately $1: 1$ with a $1 \%$ eosin blue, $2 \%$ nigrosin live-dead stain (Friars \& Chatterjee, 1969). The remaining semen was centrifuged for $30 \mathrm{~min}$ at $2000 \mathrm{~g}$ and the plasma colour was estimated (yellow or white) against a blue background.

\section{Electron microscopy of semen}

Eight samples of yellow and eight of white semen were collected from selected males. A small aliquot of each sample was taken to obtain haemocytometer counts of abnormal cells, and the remaining portion was immediately diluted with an equal volume of Millonig's buffer at $\mathrm{pH} 7 \cdot 4$ (Millonig, 1962) and gently centrifuged for $10 \mathrm{~min}$. The supernatant was then withdrawn and a few cells were aspirated from the pellet into the tip of a Pasteur pipette. The pipette was then immersed into cold $\left(4^{\circ} \mathrm{C}\right)$ Millonig's buffered $3 \%$ glutaraldehyde, followed by gentle evacuation of the cells into the glutaraldehyde solution. A long columnar-shaped clump of cells was formed that was easily infiltrated and embedded. After $1 \mathrm{hr}$ of fixation, the cells were washed twice for $10 \mathrm{~min}$ with Millonig's buffer. The samples were post-fixed using $1 \%$ Millonig's buffered osmic acid for $30 \mathrm{~min}\left(4^{\circ} \mathrm{C}\right)$ and a $2 \%$ solution for an additional $30 \mathrm{~min}\left(4^{\circ} \mathrm{C}\right)$, then dehydrated in ethanol, cleared in propylene oxide and embedded in Epon (Luft, 1961). Silver sections were cut using a 
diamond knife and post-stained for $15 \mathrm{~min}$ in $1 \%$ methanolic uranyl acetate followed by 4 min in Reynold's lead citrate (Reynolds, 1963). The sections were examined with a Philips 300 or RGA 3 G electron microscope.

\section{Electron microscopy of cultured testicular cells}

Ten males producing white semen were killed and their testes collected for the preparation of primary monolayer cultures. After incubation for 7 days the cell monolayers of the primary testicular cultures were removed with $0.25 \%$ trypsin in phosphate-buffered saline, and the cells were replated. The resulting secondary testicular cell monolayers from four males which had produced yellow semen and two which had produced white semen were fixed for electron microscopy when cellular changes typical of Herpesvirus infection had developed. The techniques used for cell cultures and electron microscopy have been previously described (Churchill, 1965; Adldinger et al., 1974).

\section{RESULTS}

\section{Light microscopy}

Of the 210 males screened, 28 were found to produce semen with deep yellow plasma, and all of these samples contained many of the cell abnormalities described below. An additional 21 males were classified as borderline cases, having slightly yellow seminal plasma with fewer semen abnormalities than the males with yellow plasma. The remaining $16 \mathrm{I}$ toms produced semen with white plasma which contained few abnormal cells. Two cell types found in semen were classified as normal: properly formed spermatozoa and large, rounded macrophages. The abnormal cells observed were classified as follows: (1) deformed spermatozoa consisting mainly of bent or bulbous heads, (2) large, rounded cells, (3) smaller, ellipsoidal cells, some of which appeared to be flagellated. The cell counts of the eight yellow and eight white semen samples were inclusive of all abnormalities, since precise differentiation into the assigned types was difficult at the light microscope level. The mean number of abnormal cells in the white semen samples was $35,200 / \mathrm{ml}$ with a range of 4000 to $56,000 /$ $\mathrm{ml}$. Macrophage counts ranged from 0 to $8000 / \mathrm{ml}$ with a mean of $4000 / \mathrm{ml}$. In contrast, the concentration of abnormal cells in the yellow semen samples was much higher, ranging from 156,000 to $932,000 / \mathrm{ml}$, with a mean of $342,400 / \mathrm{ml}$. Macrophage numbers in the yellow semen were also increased (range 16,000 to $76,000 / \mathrm{ml}$; mean $43,200 / \mathrm{ml})$.

\section{Electron microscopy}

Semen. For purposes of ultrastructural analysis, the large, round cells were classified as Type I and the smaller, elliptical cells as Type II abnormalities. The ultrastructure of abnormal spermatozoa with bent heads and coiled tails was not studied since they are seen in the electron microscope only if cut in perfect longitudinal sections. In addition, gross observations of the live-dead stain preparations usually revealed the presence of many more Type I and Type II abnormalities than there were malformed spermatozoa in yellow semen.

The Type I cells were nearly always greater than $8 \mu \mathrm{m}$ in diameter and were 
usually the most numerous abnormal cell type seen in the samples of yellow semen (Pl. 1, Fig. 2), but were rarely observed in normal white semen samples (PI. 1, Fig. 1). The ultrastructure of the Type I cells was generally pleomorphic; the cells contained organelles similar to those found in the early stages of domestic fowl spermatids (Nagano, 1962). Unlike early developing spermatids, cytoplasmic organelle organization was random in most of the Type I cells (Pl. 2, Fig. 4). When visible in appropriate sections, the nuclear chromatin appeared partly or almost completely condensed (Pl. 2, Figs 3 and 4). The mitochondria cristae were arranged parallel to the outer membrane, a characteristic of sperm mitochondria (Pl. 2, Fig. 4). Other frequently observed intracellular structures of these cells included numerous vacuoles, lamellar formations and multiples of two or more oddly shaped nuclei, centrioles or axonemal complexes (Pl. 2, Fig. 4). Occasional Type I cells were seen which presented evidence that spermiogenesis had been initiated with some degree of order as exemplified by the presence of post-nuclear centriole complexes and partly developed mitochondrial spirals (Pl. 2, Fig. 3).

Type II cells were observed in samples of white and yellow semen, although they were usually fewer in number than the larger Type I cells in the samples of yellow semen (Pl. 1, Figs 1 and 2). These cells were elongate rather than round when cut in longitudinal section (Pl. 3, Fig. 5) and their long diameter was usually less than $6 \mu \mathrm{m}$. Characteristics of the Type II abnormalities included highly condensed nuclear chromatin and complete $9+2$ axial filament complexes, typical of sperm flagellae (Bloom \& Fawcett, 1969), which were present in multiples of the normal sperm complement (Pl. 3, Fig. 5). The ultrastructure of each Type II cell was unique, and it was not uncommon for these cells to contain other sperm structures, including formed acrosomes and midpieces. As in the majority of the Type I cells, mitochondria and other organelles of these cells were randomly dispersed (Pl. 3, Fig. 5).

Seminal macrophages were easily differentiated from abnormal cells on the basis of their immense cytoplasmic vacuolation (P1. 3, Fig. 6). These cells were frequently observed in sections of the yellow semen samples, but few were seen in sections of white semen. The phagocytes were of variable size, and their diameters often exceeded $10 \mu \mathrm{m}$. The macrophages appeared to trap spermatozoa and Type II cells by the extension of pseudopodia (Pl. 3, Fig. 7; Pl. 4, Fig. 8). Evidence of engulfment of the larger cells was not seen. Remnants of spermatozoa, including mitochondria and flagellar filaments, were found in vacuoles of some of the macrophages (Pl. 4, Figs 8 and 9). Vacuoles were seen to be open to the external environment, and membranous material projected from within (Pl. 3, Fig. 6). The macrophage ultrastructure and assumed activity was similar in all the yellow and white semen samples studied. Virus particles were not detected in any cells from the yellow or white semen samples that were examined.

\section{Testicular cell cultures}

A few foci of Herpesvirus-infected cells developed within 2 weeks in the primary cultures of testis cells from the males which had produced yellow semen, but subculturing produced numerous infected cells within 3 to 7 days. It was 
PLATE 1

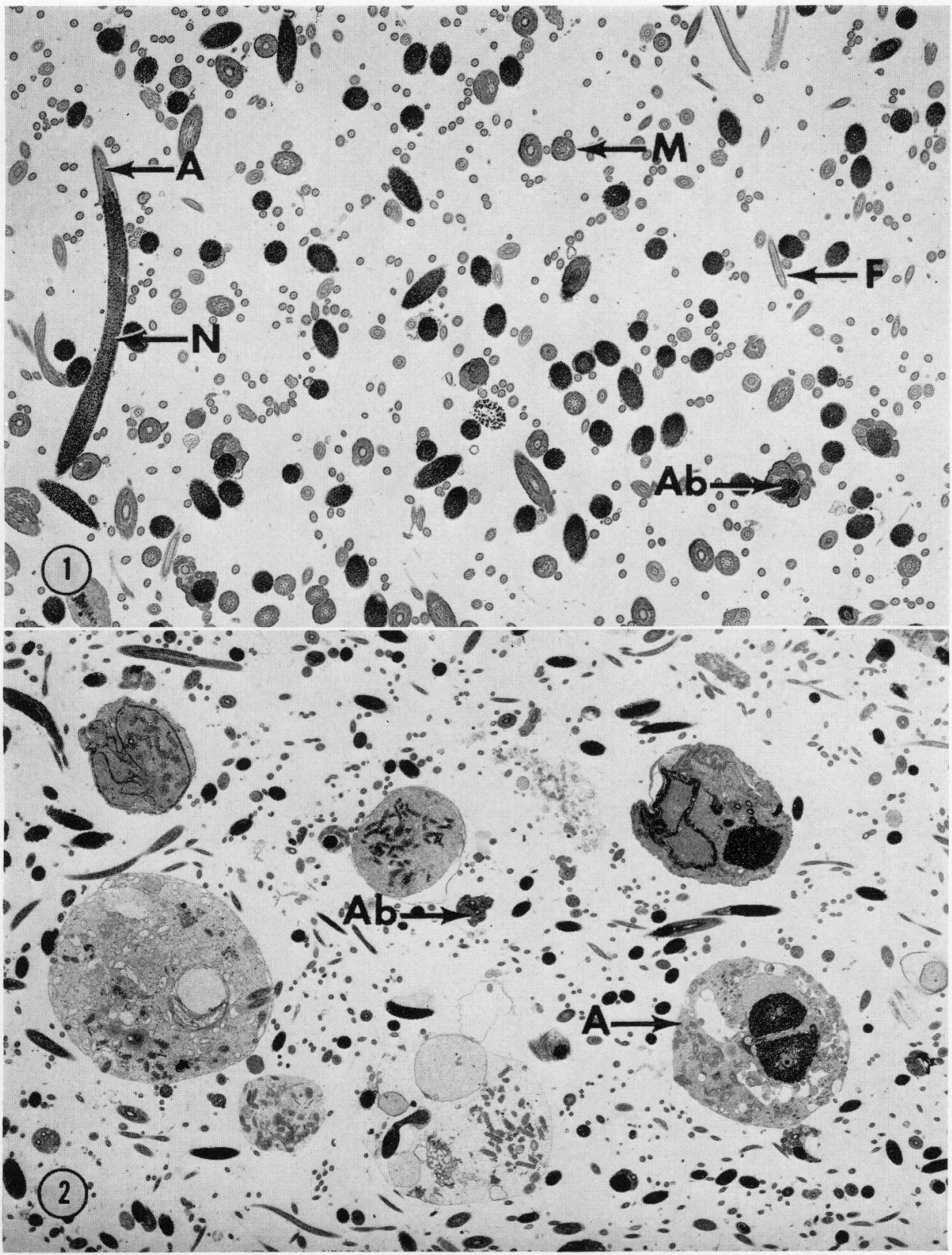

Fig. 1. Spermatozoa from a turkey male producing white semen and with no history of gross semen abnormalities. Acrosomal (A), nuclear (N), midpiece (M) and flagellar (F) regions are shown cut at various angles. A few of the smaller deformed cell types (Ab) are also present, $\times 7425$.

FIG. 2. This micrograph shows the cell types associated with yellow semen production. Large rounded cells (A) classified as Type I abnormalities occur in abundance together with the smaller Type II deformities $(\mathrm{Ab}) . \times 3375$. 
PLATE 2

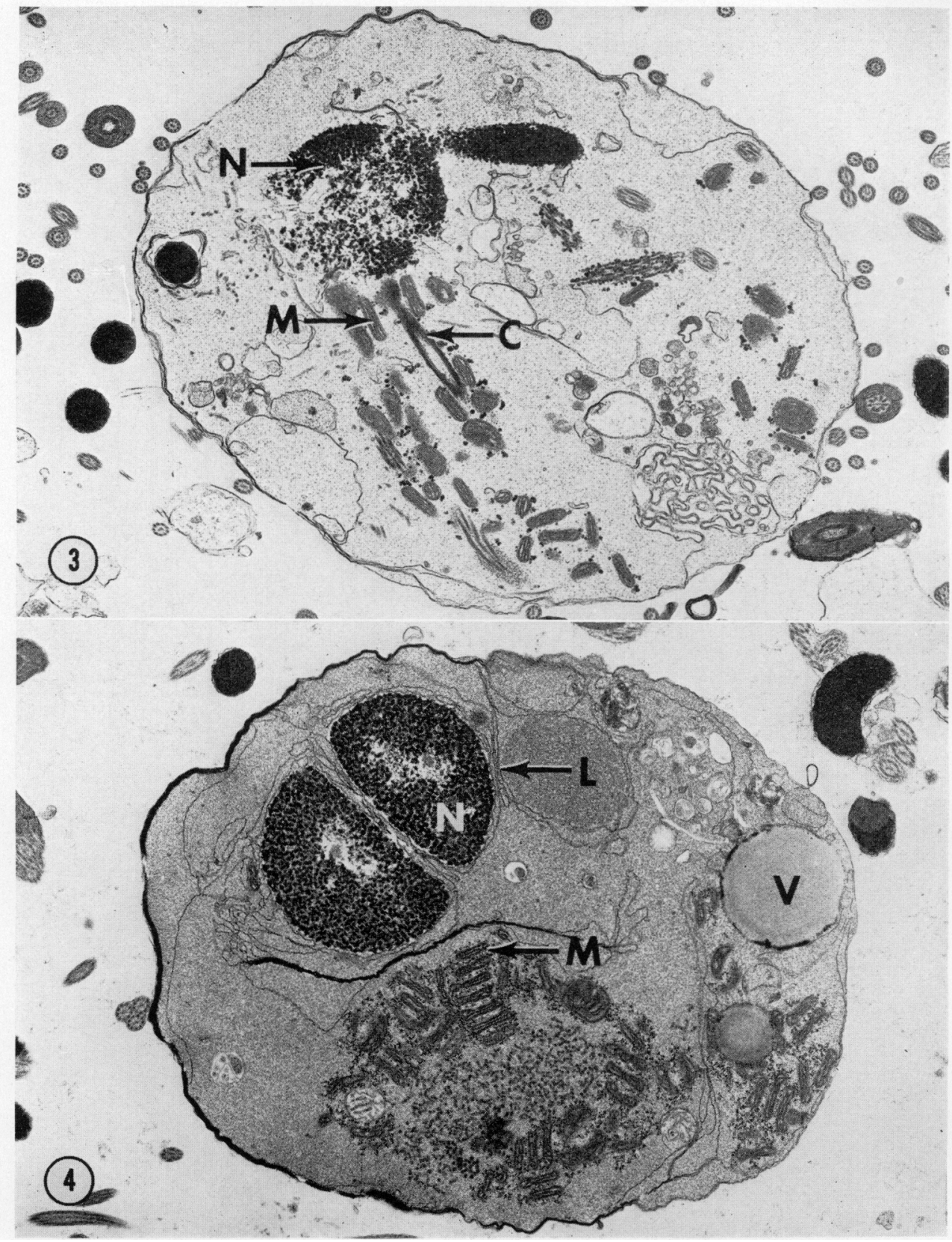

FIG. 3. Various degrees of orderly differentiation were occasionally observed in the Type I abnormal cells including partly condensed chromatin ( $\mathrm{N})$, post-nuclear alignment of the distal centrioles (C), and early formation of the mitochondrial spiral (M). $\times 10,125$.

FIg. 4. A Type I cell with ultrastructural characteristics typical of most cells of this class, including random arrangements of mitochondria (M), vacuoles (V), bizarre nuclei $(\mathrm{N})$, arrays of lamellated or filamentous membranes (L) and a finely granular cytoplasm. $\times 12,600$. 


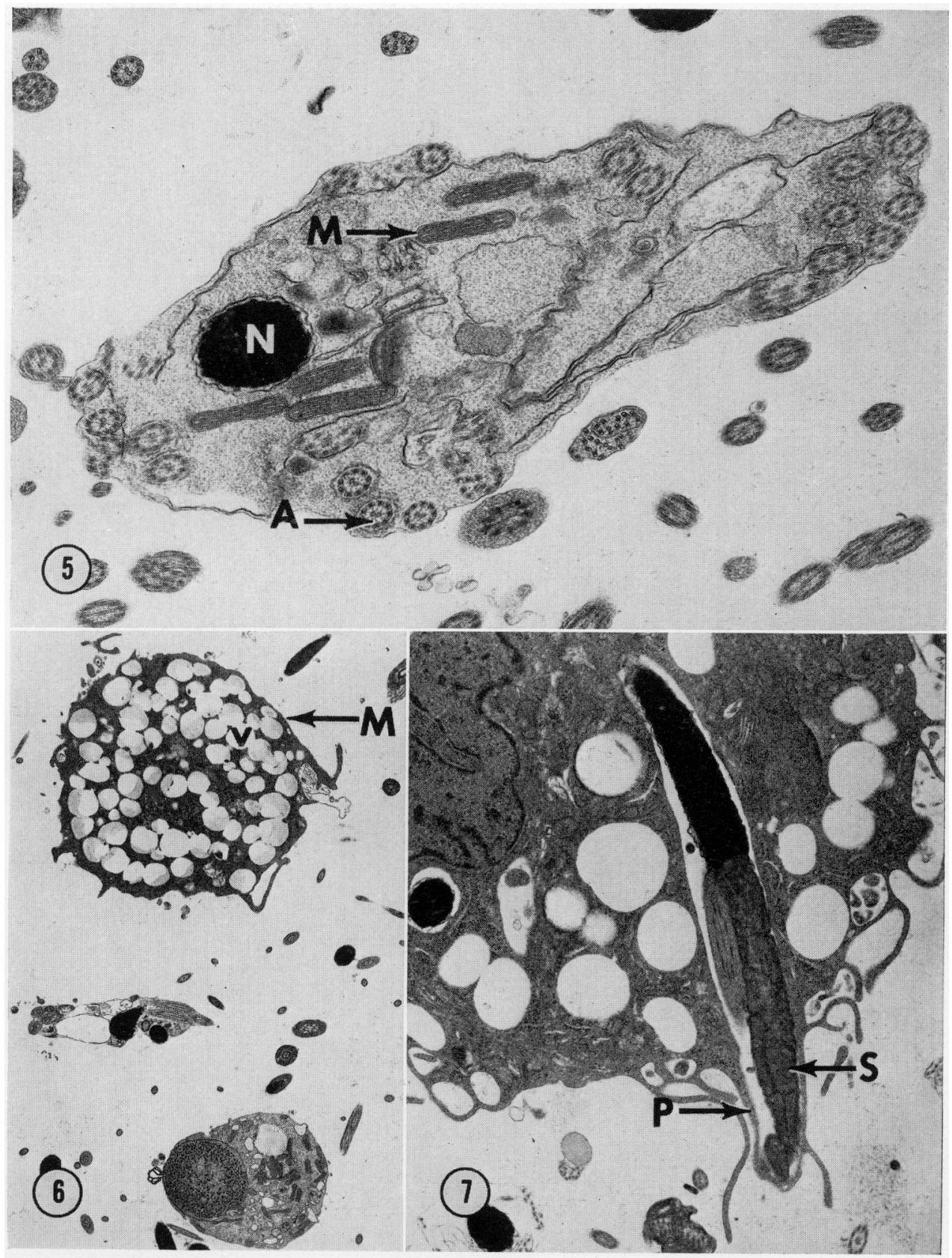

Fig. 5. A small Type II abnormal cell showing multiples of complete axonemal structures (A) which are characteristic of sperm flagella. Note the highly condensed nuclear chromatin $(\mathrm{N}) . \mathrm{M}$, mitochondria. $\times 21,000$.

FIG. 6. A seminal macrophage (M) with highly vacuolated (V) cytoplasm. This characteristic was useful in distinguishing the phagocytes from abnormal cells of Types I and II. $\times 4620$.

FIG. 7. A macrophage with pseudopodia (P) extended bilaterally around a portion of a spermatozoon $(\mathrm{S})$, an observation indicative of phagocytosis. $\times 11,480$. 
PLATE 4

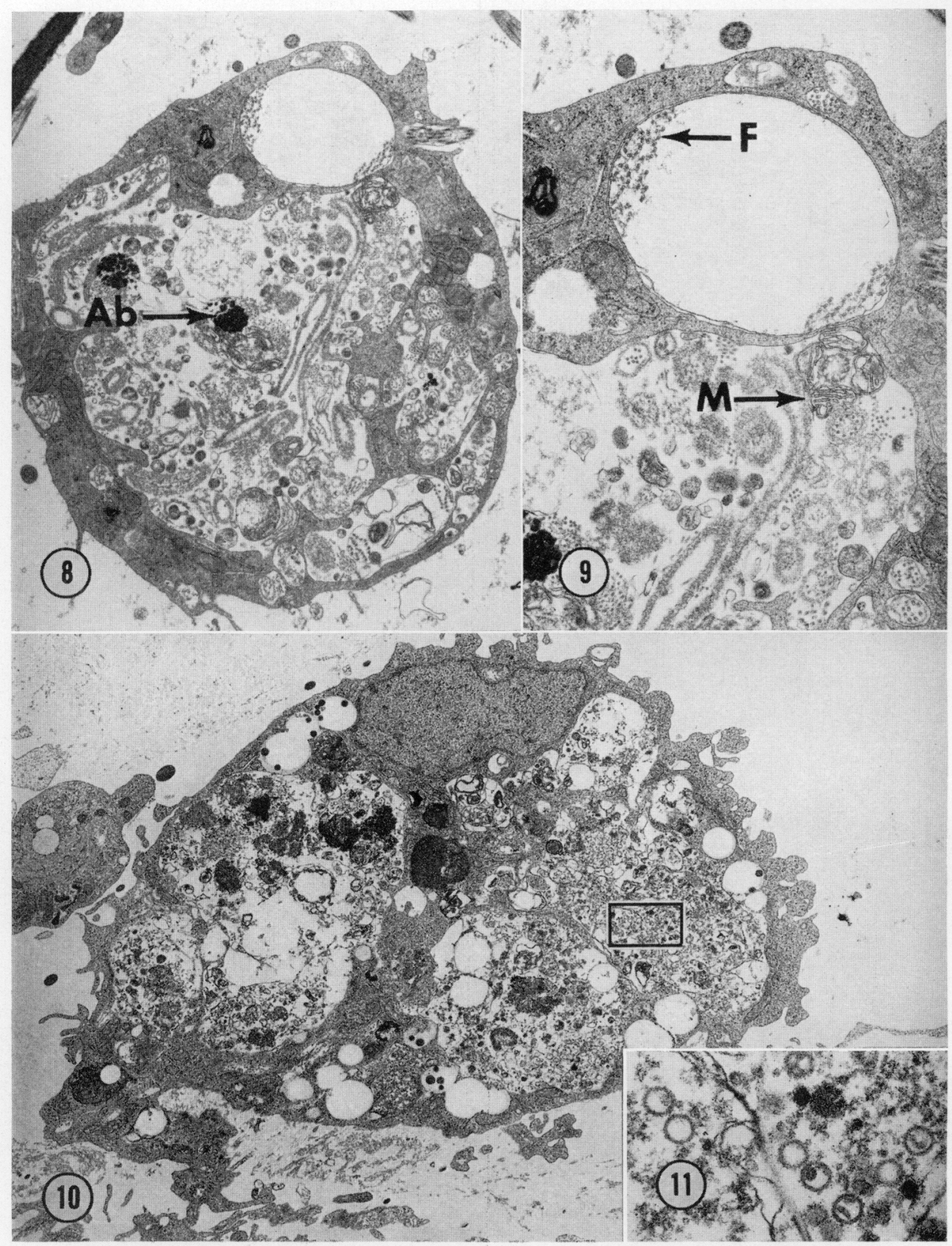

FIG. 8. This macrophage contains several sperm organelles and a partly degraded Type II abnormal cell $(\mathrm{Ab})$ within a phagocytic vacuole. $\times 9520$.

Fig. 9. Higher magnification of an area of the vacuole shown in Fig. 8. Portions of a sperm cell midpiece $(\mathrm{M})$ and axonemal filaments $(\mathrm{F})$ are apparent. $\times 16,250$.

Fig. 10. Macrophage from a culture of testicular cells. The cytoplasm contains numerous phagocytic vacuoles. Herpesvirus (Fig. 11) particles were often seen in these vacuoles, but seldom within macrophage nuclei. $\times 6600$.

Frg. 11. High magnification of the area identified by the rectangle in Fig. 10 showing immature Herpesvirus particles. $\times 41,250$. 


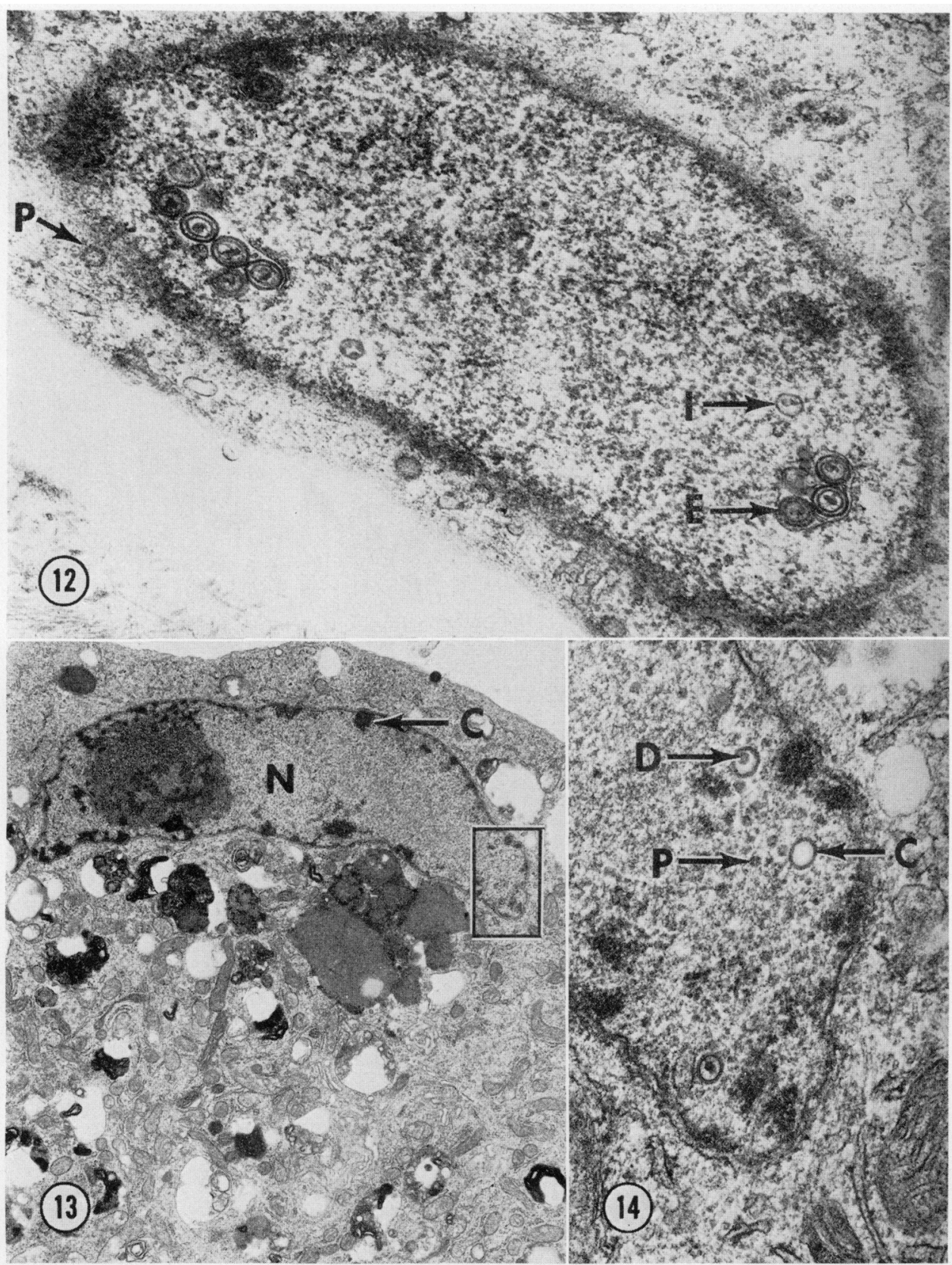

Fig. 12. Nucleus of a germinal epithelial cell cultured from the testis of a 'yellow semen' male containing mature enveloped (E) and immature naked (I) herpesviruses. Nuclear pores $(\mathrm{P})$, structures which resemble immature Herpesvirus, can be seen associated with the nuclear cnvelope. $\times 30,590$.

FIG. 13. A cultured germinal cell showing chromatin (C) which has clumped around the nuclear cnvelope, a characteristic of Herpesvirus-infected cells. N, nucleus. $\times 8680$.

Fig. 14. Area of the nuclcus outlined by the square in Fig. 13. Herpesvirus is present within the nucleoplasm: two of the particles contain dense core material (D), whereas the third is an cmpty capsid ( $\mathrm{C}$ ). Particles (P) approximately 35 to $40 \mathrm{~nm}$ in diameter, rescmbling the core material, are shown. $\times 41,850$. 
necessary to subculture the testicular cells from males with white semen and to maintain them for over 7 days to obtain enough infected cells for electron microscopic analysis. Germinal epithelial cells (Pl. 5, Fig. 13), macrophages (Pl. 4, Fig. 10) and occasional fibroblasts were found in all the secondary cultures examined. While the germinal cells could clearly be distinguished from other cell types, it was impossible to morphologically subdivide them.

Herpesvirus particles, most of which were intranuclear, were found in the cultured germinal cells from males producing yellow or white semen (Pl. 5, Figs 12 and 14). Macrophages (Pl. 4, Fig. 10) were present in large numbers in every culture examined, but seldom contained intranuclear Herpesvirus. Virus particles were often seen within phagocytic vacuoles of the macrophages (Pl. 4, Fig. 11) in cultures from producers of yellow semen. Particles approximately $100 \mathrm{~nm}$ in size were either empty or core-containing capsids (Pl. 5, Figs 12 and 14). Variations in the arrangement of the core material accounted for the different morphological entities, including electron-lucent cross formations (PI. 5, Fig. 12). Dense particles 35 to $40 \mathrm{~nm}$ in diameter were often seen within the nucleoplasm of infected cells (P1. 5, Fig. 14). These particles were always associated with the presence of nucleocapsids, some of which contained core material that morphologically resembled the free dense particles. Enveloped particles of approximately $160 \mathrm{~nm}$ in diameter were occasionally seen within nuclear vesicles (Pl. 5, Fig. 12). Nazerian et al. (1971) reported that turkey herpesviruses also appear to undergo envelopment within the cytoplasm, but no evidence of this was seen in the cells examined in this study.

\section{DISGUSSION}

Abnormal sperm cell production probably occurs in all turkey breeder males and appears to intensify as the breeding season progresses (Kamar \& Rizik, 1972). The work of Saeki \& Brown (1962) and the results presented in the present study have shown that yellow turkey semen contains several abnormal cells and this may account for the lowered fertility associated with males producing yellow semen (Cherms, 1968). While Saeki \& Brown (1962) identified crooked-necked spermatozoa as the major abnormality present in yellow semen, we found that malformed spermatids were the dominant abnormal cells. This may be because malformed spermatids are not detected in living preparations examined by light microscopy because of their translucent nature.

Electron microscopic analysis of semen samples enabled us to define two types of malformed cells. On the basis of the observed ultrastructural details, it was concluded that both types of abnormalities originated in the seminiferous tubules rather than in ductal epithelia or supportive tissues and indeed were spermatids. The ultrastructural differences between Type I and II abnormalities indicated that the malformation may have occurred at different stages of spermiogenesis, e.g. as early and late spermatids, respectively.

The ultrastructural study of McIntosh \& Porter (1967) has shown that the proper chronological assembly of microtubules into a manchette adjacent to the spermatid nucleus is essential for development and curvature of sperm 
nuclei in the domestic chicken. No paranuclear microtubules were seen in the abnormal seminal spermatids examined in this study, although we have observed such structures in spermatids lining the epithelium of seminiferous tubules from both white and yellow semen producers. Faulty microtubule assembly, as suggested by McIntosh \& Porter (1967), may explain the apparent abnormal differentiation we have observed in spermatids.

The finding of increased macrophage numbers in the yellow semen was not surprising, since abnormal sperm cells have been shown to attract macrophages in other species (Phadke \& Phadke, 1961; Phadke, 1964; Roussel et al., 1967; Crabo et al., 1971). From the electron microscopic evidence obtained in this study it appeared that the phagocytic activity of macrophages in the yellow semen samples was directed at spermatozoa and abnormal spermatids of Type II. An unexplained phenomenon was that abnormal spermatids of Type I were never seen to be engulfed although macrophages occasionally contained vacuoles of an equal or greater diameter than the larger abnormal spermatids.

The source of seminal macrophages is still the subject of discussion. Sertoli cells, lymphocytes, and epithelial cells of the ducts have all been implicated as seminal phagocytes (Tjioe \& Steinberger, 1967; Carr et al., 1968; Atwal \& McFarland, 1971; Tingari \& Lake, 1972). Our observation that cultures of testicular cells contained macrophages which morphologically resembled the seminal phagocytes lends support to the hypothesis that seminal phagocytes may also originate in the seminiferous tubules.

In this study, Herpesvirus was not detected in sections of seminal cells from producers of yellow or white semen. Nor was Herpesvirus found within any epithelial cell type lining the seminiferous tubules of testis fixed immediately post mortem from males of either type (unpublished data). In contrast, germinal epithelial cells and macrophages in secondary cultures of testicular cells, particularly those from males producing yellow semen, contained numerous Herpesvirus particles. This is in agreement with our previously reported study (Adldinger et al., 1974) in which viral antigens were not found in testis tissues although infectious virus was regularly isolated from secondary testis cultures. It is possible, therefore, that the testis cells in vivo were for the most part latently infected. A level of virus replication in the testes low enough to escape the above examinations would explain the sporadic recovery of virus from the semen (Adldinger $\mathrm{et} \mathrm{al.,} \mathrm{1974).} \mathrm{However,} \mathrm{virus} \mathrm{replication} \mathrm{may} \mathrm{not} \mathrm{be} \mathrm{a} \mathrm{prerequisite} \mathrm{for}$ infecting herpesviruses to interfere with the normal differentiation of cells during spermiogenesis, although this could be different with other viruses (Fernandes et al., 1973).

\section{ACKNOWLEDGMENTS}

The authors are extremely grateful for the assistance given in electron microscopy by Dr M. Brown, Dr J. White and Mr R. Faup. We would also like to thank Dr E. McCune for assisting with the necropsy and histopathology. Animals used in this study were kindly made available by Dr A. Stephenson.

This publication is a portion of a dissertation submitted to the Graduate Faculty of the University of Missouri-Columbia in partial fulfilment of the 
requirements for the degree of Doctor of Philosophy by the senior author, and is a contribution from the Missouri Agricultural Experiment Station (Journal Series Number 7175).

\section{REFERENCES}

Adldinger, H.K., Thurston, R.J., Solorzano, R.F. \& Bieliler, H.V. (1974) Herpesvirus-a possible cause of infertility in the male turkey. Arch. ges. Virusforsch. 46, 370-376.

Atwal, O.S. \& McFarland, L.Z. (1971) Carbon uptake response by Sertoli cells and epithelial cells lining the duct system of the Japanese quail (Coturnix coturnix japonica). Poult. Sci. 50, 159-166.

Bloom, W. \& Fawcet, D.W. (1969) A Textbook of Histology, 9th edn, pp. 696-697. Saunders, Philadelphia.

Burrows, W.H. \& Quin,, J.P. (1937) The collection of spermatozoa from the domestic fowl and turkey. Poult. Sci. 16, 19-24.

Carr, I., Glegg, E.J. \& Meek, G.A. (1968) Sertoli cells as phagocytes: an electron microscopic study. 7. Anat. 102, 501-509.

Cherms, F.L. (1968) Variations in semen quality and the relationship of semen quality to fertility in turkeys. Poult. Sci. 47, 746-754.

Churchill, A.E. (1965) The use of chicken kidney tissue culture in the study of the avian viruses of Newcastle disease, infectious laryngotracheitis and infectious bronchitis. Res. vet. Sci. 6, 162-169.

Grabo, B., Gustafsson, B., Nicander, L. \& Rao, A.R. (1971) Subnormal testicular function in a bull concealed by phagocytosis of abnormal spermatozoa in the efferent ductules. 7 . Reprod. Fert. 26, 393 -396 .

Fernandes, G., Yunis, E.J., Yunis, E.J. \& Good, R.A. (1973) Reproductive deficiency of NZB male mice. Possibility of a viral basis. Lab. Invest. 29, 278-281.

Friars, G.W. \& ChatTerjee, S. (1969) Effects of semen collection and storage temperatures on sperm viability and fertility in turkeys. Poult. Sci. 48, 1434-1437.

KamaR, G.A.R. \& RizIK, M.A.A. (1972) Semen characteristics of two breeds of turkeys. $\mathcal{F}$. Reprod. Fert. 29, 317-325.

Kammerer, D.M., Moreng, R.E., Uller, H.D. \& Hobes, H.W. (1972) Turkey semen evaluation for fertility prediction. Poult. Sci. 51, 77-82.

Lorenz, F.W. (1970) Turkey A.I. and fertility. Proc. 3rd Tech. Conf. A. I. E̊ Reprod., Chicago, pp. 95-100.

LuFT, J.H. (1961) Improvements in epoxy resin embedding methods. F. biophys. biochem. Cytol. 9, 409414.

McCartney, M.G. (1956) Relation between semen quality and fertilizing ability of White Holland turkeys. Poult. Sci. 35, 137-141.

MaIntosh, R.J. \& Porter, K.R. (1967) Microtubules in the spermatids of the domestic fowl. F. Cell Biol. 35, 153-173.

Millonig, G. (1962) Further observations on a phosphate buffer for osmium solutions in fixation. In Proc. 5th Int. Congr. Electron Microsc., Philadelphia, Vol. 2, p. 8. Ed. S. S. Breese. Academic Press, New York and London.

Nagano, T. (1962) Observations on the fine structure of the developing spermatid in the domestic chicken. 7. Cell Biol. 14, 193-205.

Nazerian, K., Lee, L.F., WitTer, R.L. \& BuRmester, B.R. (1971) Ultrastructural studies of a Herpesvirus of turkeys antigenically related to Marek's disease virus. Virology 43, 442-452.

Phadke, A.M. (1964) Fate of spermatozoa in cases of obstructive azoospermia and after ligation of vas deferens in man. 7. Reprod. Fert. 7, 1-12.

Phadke, A.M. \& Phadke, G.M. (1961) Occurrence of macrophage cells in the semen and in the epididymis in cases of male infertility. 7 . Reprod. Fert. 2, 400-403.

REynolds, E.S. (1963) The use of lead citrate at high $\mathrm{pH}$ as an electron-opaque stain in electron microscopy. 7. Cell Biol. 17, 208-212.

Roussel, J.D., Stallaup, O.T. \& Austin, G.R. (1967) Selective phagocytosis of spermatozoa in the epididymis of bulls, rabbits and monkeys. Fert. Steril. 18, 509-516.

SAEKI, Y. (1960) Crooked-necked spermatozoa in relation to low fertility in the artificial insemination of fowl. Poult. Sci. 39, 1354-1361.

SAEKI, Y. \& BROWN, K.I. (1962) Effect of abnormal spermatozoa on fertility and hatchability in the turkey. Poult. Sci. 41, 1096-1100.

TingaRI, M.D. \& LAKE, P.E. (1972) Ultrastructural evidence for resorption of spermatozoa and testicular fluid in the excurrent ducts of the testis of the domestic fowl, Gallus domesticus. $\mathcal{F}$. Reprod. Fert. 31, 373-381.

Tjioe, D.Y. \& Steinberger, E. (1967) Spermiophages in human testes. Fert. Steril. 18, 807-811. 